\title{
MELESTARIKAN KEARIFAN BUDAYA LOKAL MELALUI PERMAINAN TRADISIONAL ULAR TANGGA
}

\author{
Oleh. \\ I Kadek Hadi Suananda \\ Mahasiswa Program Magister Pendidikan Bahasa dan Sastra Agama \\ Institut Hindu Dharma Negeri Denpasar \\ kadekadi520@gmail.com \\ Kadek Aria Prima Dewi PF \\ Institut Hindu Dharma Negeri Denpasar \\ primadewipf@gmail.com
}

\begin{abstract}
This article aims to illustrate the application of traditional snake ladder games in the learning process to preserve local cultural wisdom. This is motivated by the phenomenon of current student activity changes, which more often play modern games that are identical with the use of technology such as video games and online games. As a result, the traditional student games are beginning to be forgotten and become alien among the students. In addition, the level of addiction to the modern game on the students is also high so it affects the habits and behavior of students. As a cultural heritage containing noble values, the traditional game should be preserved And maintained its existence by introducing traditional games through the process of learning in the classroom. One of the traditional games that can be applied in the process of learning in the classroom is a snake ladder game. In this article the method used is the method of observation. Based on the observation results obtained that the traditional games can stimulate students in developing cooperation in groups in the learning process, , Interact as positively, can condition students in self-control, develop empathy for friends, obey the rules, and appreciate others. Thus, it is understood that traditional games can have an excellent impact in helping to develop students' emotional and social skills.
\end{abstract}

\section{Keywords: Traditional game, Snake game ladder, syntax game snake ladder}

\section{PENDAHULUAN}

Setiap siswa memiliki keunikan tersendiri dalam belajar. Untuk itu, dalam membantu pembelajaran siswa, tenaga pendidik harus mampu menelusuri bakat dan minatnya, mendorong, menghargai, dan menanamkan kepercayaan diri sekaligus terlibat langsung dalam proses pembelajaran. Pembelajaran yang paling baik untuk siswa adalah belajar sambil bermain. Dengan bermain, mereka bisa menyerap unsur-unsur pembelajaran yang terkandung dalam bentuk permainan.Melalui kegiatan bermain atau kegiatan melakukan permainan sangat memungkinkan siswa- siswa untuk bertemu teman sebaya, maka bermain dianggap sebagai media yang penting untuk bersosialisasi. Bermain juga membantu siswa dalam menjalin hubungan sosial 
antar siswa, mengembangkan imajinasi mereka, mengembangkan kognisi, bahasa dan motorik kasar dan halus. Siswa menggunakan gerakan dan kemampuan fisiknya, melatih kreativitas, dan mengasah kemampuannya menyelesaikan masalah dengan rnenghadapi berbagai permainan, dan bermain dapat membantu bahasa siswa melalui interaksi dengan teman sebaya dan lingkungan.Jadi bermain bagi siswa tidak sekedar menghabiskan waktu, tetapi merupakan media bagi siswa untuk belajar.Salah satu permainan yang dapat dikenalkan pada siswa adalah permainan tradisional.

Permainan tradisional adalah permainan yang berkembang dan dimainkan siswa dalam lingkungan masyarakat umum dengan menyerap segala kekayaan dan kearifan lingkungannya.Sebagai warisan budaya yang mengandung nilai-nilai luhur, permainan tradisional hendaknya dilestarikan dan dipertahankan keberadaanya.Unsur ini merupakan sebuah sarana sosialisasi yang efektif dari nilainilai yang dipandang penting oleh suatu masyarakat.Permainan tradisional terbukti mampu mengajarkan kemandirian kepada siswa. Tidak hanya itu, permainan tradisional juga cenderung melatih kemampuan fisik dan mental siswa agar kuat menghadapi masalah dan persaingan terutama dalam proses pembelajaran dikelas.

Namun pada kenyataannya dalam proses pembelajaran saat ini tenaga pendidik cenderung lebih banyak memperkenalkan permainanpermainan baru yang lebih modern dalam proses pembelajaran dikelas. Salah satu contohnya yaitu permainan tebak gambar dan tebak kata dengan pemanfaatan teknologi, meskipun permainan tersebut baik digunakan dalam proses pembelajaran namun tidak pula meninggalkan permainan tradisional sebagai warisan budaya. Berdasarkan hasil pengamatan yang dilakukan bahwa sebagian besar siswa pada zaman sekarang kurang mengenal permainan-permainan tradisional seperti permainan congklak, bekel, ular tangga, dan sebagainya.Hal ini menunjukkan bahwa dari lingkungan keluarga, siswa belum diperkenalkan tentang permainan-permainan tradisional padahal permainan tradisional memberikan manfaat yang luar biasa terhadap perkembangan siswadibandingkan dengan memberikan siswa permainan melalui handphone atau laptop.

Berdasarkan permasalahan yang muncul diatas maka untuk melestarikan permainan tradisonal agar kembali dikenal di kalangan masyarakat salah satu permainan tradisional yang dapat digunakan adalah permainanular tangga.Permainan ular tangga adalah permainan papan untuk siswa-siswa yang dimainkan oleh dua orang atau lebih.Strategi permainan ular tangga merupakan jenis permainan atraktif yang melibatkan siswa berperan aktif dalam ular tangga (Said dkk, 2015).Permainan ular tangga dapat digunakan pada semua mata pelajaran.

Berdasarkan latar belakang tersebut maka rumusan masalah dalam artikel ini adalah apakah manfaat yang didapatkan dari penerapan permainan tradisional ular tangga dalam proses pembelajaran guna melestarikan kearifan budaya lokal? 


\section{METODE}

Pengumpulan data merupakan tahapan yang penting dilakukan untuk memperoleh informasi yang dibutuhkan dalam rangka mencapai tujuan penelitian.Metode pengumpulan data yang digunakan pada artikel ini adalah metode observasi.Metode observasi merupakan salah satu teknik pengumpulan data yang tidak hanya mengukur sikap dari responden (wawancara dan angket) namun juga dapat digunakan untuk merekam berbagai fenomena yang terjadi (situasi, kondisi).Teknik ini digunakan bila penelitian ditujukan untuk mempelajari perilaku manusia, proses kerja, gejala-gejala alam dan dilakukan pada responden.

Pada permainan ular tangga ini, tidak sulit menggunakannya dalam pembelajaran sepanjang dalam permainan ular tangga dan kartu soal sudah disiapkan terlebih dahulu.Berikut langkah-langkah menggunakan permainan tradisional ular tangga (Said dkk, 2015).

1) Tiap siswa dalam kelompok membuat sebuah pertanyaan yang disesuaikan dengan materi ajar yang akan dipelajari

2) Setelah selesai membuat pertanyaan, semua pertanyaan dimasukkan kedalam kotak

3) Siapkan papan permainan ular tangga dengan jumlah 50 kotak (disesuaikan dengan alokasi waktu) serta dadu yang mempunyai mata enam

4) Tiap kelompok bergantian melempar dadu
5) Jika dadu yang jatuh menunjukkan mata dadu 5, maka siswa harus berjalan 5 kotak pada papan permaian ular tangga

6) Jika sudah dijalankan, siswa harus mengambil satu buah pertanyaan dari dalam kotak dan siswa menjawab pertanyaan tersebut bersama kelompoknya. Jika jawabannya benar maka siswa tersebut akan mendapatkan poin berupa tanda checklist $(\sqrt{ })$ namun jika jawabannya salah maka siswa bersama kelompok tersebut akan mendapat hukuman

7) Apabila kotak yang dituju didapati gambar ular dengan posisi turun maka pemain harus mengikuti posisi ular turun

8) Pemenang dari permainan ini adalah siswa yang paling banyak menjawab pertanyaan dengan benar dan terlebih dahulu finis atau berada pada kotak dengan angka lebih besar.

\section{HASIL DAN PEMBAHASAN}

Berdasarkan data hasil pengamatan diperoleh hasil bahwa permainan tradisional ular tangga dapat mestimulasi siswa dalam mengembangkan kerjasama dalam tim dalam proses pembelajaran dikelas, membantu siswa menyesuaikan diri, saling berinteraksi secara positif, dapat mengkondisikan siswa dalam mengontrol diri, mengembangkan sikap empati terhadap teman, menaati aturan, serta menghargai pendapat orang lain. Hal ini terlihat 
dari cara siswa dalam berinteraksi dengan teman-teman didalam kelas dalam proses pembelajaran serta keterlibatan aktif siswa didalam kelas sehingga secara tidak langsung siswa belajar melalui pengalaman yang didapatkan. Permainan ular tangga ini memberikan manfaat yang luar biasa selain sebagai wadah untuk melestarikan kearifan budaya lokal juga memperkenalkan siswa sejak dini tentang permainan tradisional melalui kegiatan pembelajaran di kelas. Dari hasil pengamatan juga terlihat siswa sangat antusias dalam mengikuti proses pembelajaran didalam kelas dengan belajar sambil bermain. Melihat keadaan tersebut maka permainan tradisional perlu dikembangkan dalam proses pembelajaran sehingga siswa tidak hanya mengenal permainanpermainan modern tetapi juga mengenal tentang permainanpermainan tradisional yang merupakan warisan nenek moyang yang harus tetap dijaga kelestariannya.

Manfaat dari permainan ular tangga ini dilihat dari segi kognitif yaitu dapat menambah pengetahuan dan daya ingat anak terhadap materi yang telah disampaikan.Jika dilihat dari segi afektif permainan ular tangga ini mengajarkan anak untuk bersikap sportif, bekerjasama dalam tim, dan saling menghargai pendapat orang lain. Kemudian jikadilihat dari segi psikomotorik permainan ini dapat melatih keterampilan anak dalam menyampaikan pendapat, keterampilan dalam penjumlahan dan pengurangan.Dengan demikian, dapat dipahami bahwa permainan tradisional dapat memberikan dampak yang sangat baik dalam membantu mengembangkan

keterampilan emosi dan social siswa.

\section{SIMPULAN DAN SARAN}

Berdasarkan hasil pengamatan yang telah dilakukan maka dapat disimpulkan bahwa permainan tradisional adalah permainan yang berkembang dan dimainkan siswa dalam lingkungan masyarakat umum dengan menyerap segala kekayaan dan kearifan lingkungannya.Permainan tradisional ini dapat dikembangkan melalui pembelajaran di kelas.Salah satu permainan yang dapat diterapkan adalah permainan ular tangga. Pada permainan ular tangga ini secara tidak langsung mengajarkan siswa tentang sikap sportif, menghargai pendapat orang lain, serta kerjasama dalam tim. Dalam hal ini dapat dilihat dari antusias siswa dalam proses pembelajaran dengan menerapkan permainan ular tangga.Selain itu dalam permainan ular tangga ini memberikan manfaat yang luar biasa yaitu dari segi kognitif yaitu dapat menambah pengetahuan dan daya ingat anak terhadap materi yang telah disampaikan.Jika dilihat dari segi afektif permainan ular tangga ini mengajarkan anak untuk bersikap sportif, bekerjasama dalam tim, dan saling menghargai pendapatorang lain. Kemudian jikadilihat dari segi psikomotorik permainan ini dapat melatih keterampilan anak dalam menyampaikan pendapat, keterampilan dalam penjumlahan dan pengurangan.Dengan demikian permainan ular tangga ini sangat baik diterapkan melalui kegiatan pembelajaran di kelas sebagai 
warisan budaya dan tetap harus dilestarikan.

Berdasarkan temuan-temuan dalam penemuan ini, ada beberapa saran yaitubagi guru disarankan untuk lebih banyak mengenalkan budaya-budaya lokal melalui permainan tradisional dalam proses pembelajaran sehingga siswa mengenal permainan-permainan tradisional sebagai warisan budaya. Bagi siswa disarankan untuk lebih banyak mengenal permainanpermainan tradisional dibandingkan dengan permainan masa kini sehingga permainan tradisional tetap dilestarikan meskipun bersaing di era globalisasi ini.

\section{DAFTAR PUSTAKA}

Aunurrahman. 2009. Belajar dan Pembelajaran. Cetakan Ke3. Bandung: Alfabeta.

Said, Alamsyah dkk. 2015. 95 Strategi Mengajar Multiple Intelligences. Cetakan Ke1. Jakarta: Kencana Prenadamedia Group

Mulyani, Novi. 2016. Super Asyik Permainan Tradisional Anak Indonesia. Cetakan Ke-1. Yogyakarta: DIVA Pres.

Haerani Nur. 2012. Membangun Karakter Anak Melalui Permainan Anak Tradisional.Universitas Negeri Makasar 